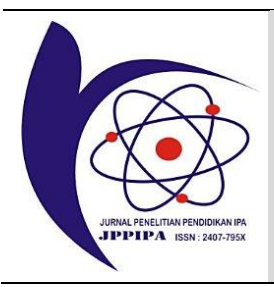

\title{
Development of Phet Simulation-Assisted Inquiry Model Learning in Elasticity Materials
}

\author{
Yuliana $^{1^{*}}$, Wahyudi ${ }^{1}$, Aris Doyan ${ }^{1,2}$, Chester Ian S. Pineda ${ }^{3}$ \\ ${ }_{1}^{1}$ Physics Education Study Program, MIPA Education Department, University of Mataram, Lombok, West Nusatenggara, Indonesia. \\ ${ }^{2}$ Magister Science Program, Postgraduate, University of Mataram, Lombok, West Nusatenggara, Indonesia. \\ ${ }^{3}$ Special Science Teacher I, Department of Education Libertad National High School, Philippines.
}

\section{DOI: $10.29303 /$ ippipa.v7i2.505}

\section{Article Info}

Received : November $12^{\text {th }}, 2020$

Revised : April 2th, 2021

Accepted: April 6th, 2021

\begin{abstract}
This research aims to produce Phet simulation-assisted guided inquiry model learning devices on valid, effective, and practical elasticity materials. This research uses research and development (R\&D methods with research models developed are 4D Models consisting of Define, design, development, and disseminate stage. Products from research in the form of syllabus, Learning Implementation Plan, Student Worksheet, and Instrument Learning Results Test. The results showed that 1 ) the validity results of the six validators using content validity ratio (CVR) and Content Validity Index (CVI) calculations showed a value of 1 (very valid) for all developed products, 2) teacher and learner responses to learning referring to the guided incubation learning model assisted by Phet simulation is very practical, as well as 3 ) guided incubation learning model-assisted Phet simulation is effectively used in learning. From the results of the study, it can be concluded that the development of learning devices is valid, effective, and practical.
\end{abstract}

Keywords: Development; Learning tools; Guided inquiry learning models; Phet simulation; elasticity material

Citation: Yuliana, Y., Wahyudi, W., Doyan, A., \& Pineda, C. (2021). Development of Phet Simulation-Assisted Inquiry Model Learning in Elasticity Materials. Jurnal Penelitian Pendidikan IPA, 7(2), 178-183. doi:https://doi.org/10.29303/jppipa.v7i2.505

\section{Introduction}

Education in Law No. 23 of 2003 is a conscious and planned effort to realize the learning atmosphere and learning process so that students actively develop their potential to have religious-spiritual strength, selfcontrol, personality, intelligence, noble morals, as well as the skills necessary for themselves, society, nation, and country (Ministry of Education, 2003). Education is one of the important components of the future because it is always prioritized to prepare for the role of students in the future. The purpose of national education is to develop the potential of students to become human beings who believe and fear the one true god, noble, healthy, know-how, capable, creative, independent, and become democratic and responsible citizens. The way to achieve the objectives of education is to load natural sciences as mandatory subjects for students in schools.

Physics is part of science that focuses its studies on matter, energy, and the relationship between the two (Gunawan, 2015). According to Sari (2017), Physics is one of the parts of science that studies various objects in nature, symptoms, and phenomena that occur in nature. Physics learning emphasizes providing first-hand experience to develop student competencies. Learning is directed to find out and do so to help students gain a deeper experience of the environment.

Related to this, improving the learning process can be done by making the learning atmosphere and learning process good so that the potential of students develop to the maximum and can create good quality and learning outcomes. Therefore it can be said that the 
root end of the educational process can be observed in terms of the learning process.

The learning process is essentially an educator process that is not merely technical teaching, there must be communication involving educators and learners because basically humans grow and develop in their relationships. A one-way learning process does not support the participation of students in the learning process.

The results of observation of learning in the classroom and interview with one of the physics teachers in MAN 1 West Lombok school, physics learning that has been carried out using direct learning methods and still applying the activeness of teachers in their learning activities. Learning tends to be one-way so that the involvement of students actively in the learning process is still lacking. In addition, the Covid-19 pandemic requires people to work from home (WFH), a study from home, and social distancing. Students are required to participate in learning with an online system, the limitations of internet access in online learning will cause students not to receive learning fully, if the learner does not understand the material taught by the teacher, this will have an impact on the learning results of the learner.

Development Research in education is an industry-based development model in which the findings of the study are used to design learning products, which are then systematically tested in the field, evaluated, and refined until the production of a learning product that meets certain standards of effective, efficient, and quality (Borg \& Gall, 1983). Development research aims to produce learning tools, such as syllabuses, teaching materials, media, practicum modules, student work exercises, learning progress measuring tools, learning outcomes measuring tools.

Learning tools are a supporting tool in learning that is used for students (Tanjung, 2018). One to facilitate the development of the skills and learning outcomes of students, then in this study it is necessary to do the development of learning devices guided by Phet simulation. Furthermore, Susdarwati (2016) states that developed devices such as lesson plan, and students worksheet. The developed device is expected to be used by teachers as an effective and efficient development medium.

Inquiry Learning is a process for obtaining and obtaining information by making observations or experiments to find answers or solve problems using thinking and logical skills (Abidin, 2014). Based on the role of teachers in learning, the Standard for Science Teacher Preparation (NSTA \& AETS) in Sarwi \& Khanafiyah (2010) states the inquiry is grouped into three, namely discovery learning, guided inquiry, and open inquiry. The guided assisted learning model is a teaching model that allows students to step by step from identifying problems, defining hypotheses, formulating problems, collecting data, verifying results, and generalizing conclusions. According to Kholifudin (2012) and Maliyah (2012), students who study with inquiry guided through experiments achieve better performance than students who study using demonstrations. Wulandari (2014) stated that the study results of students who applied the inquiry learning model were guided higher than those of students who learned using lecture methods. The model of guided inquiry learning is inseparable from the experiment in the laboratory. On the other hand, computer simulations have the potential to allow students to conduct experiments virtually like real laboratories (Finkelstein, 2005). Using a virtual laboratory is an investigationbased activity that encourages curiosity and investigation with certain techniques to find your own answers to problems. One of the virtual laboratories used is Phet simulation.

\section{Method}

\section{Types of Research}

This research uses research and development methods with research models developed are 4D Models consisting of defining, designing, development, and dissemination stage. This research is intended to develop a guided assisted model learning device assisted by Phet simulation on elasticity material.

This development research was conducted at MAN 1 West Lombok odd semester in AugustSeptember 2020. The subject of this study was a class XI MIA 1 learner at MAN 1 West Lombok. The type of data in the development of learning devices guided by Phet simulation-assisted in elasticity materials is qualitative and quantitative data. Qualitative data is obtained from validation results in the form of advice from expert validators and practitioners, in the form of comments or suggestions for revision materials. While quantitative data is obtained from validation results by expert validators and response data of students.

\section{Data Retrieval Instruments}

Data collection instruments are needed as a tool to measure the feasibility of developed learning devices. The data collection instruments used are validation, questionnaire, and test sheets.

\section{Data Analysis Techniques}

\section{Validity of Data Analysis}

Before being used for limited tests, learning devices such as syllabus, lesson plan, students worksheet, and Learning Results Test Instruments were validated by 3 expert lecturers and 3 practitioners. The 
validity of learning devices is calculated using the content validity ratio (CVR) and Content Validity Index (CVI). The way to calculate the CVR value is to use equation (1).

Validity Ratio (CVR) Formula:

$$
\mathrm{CVR}=\frac{\mathrm{Ne}-\frac{\mathrm{N}}{2}}{\frac{\mathrm{N}}{2}}
$$

Description:

$\mathrm{N}_{\mathrm{e}}=$ number of validators who agree

$\mathrm{N}=$ total number of validators

Furthermore, CVI is also calculated which is an indication of the validity of the contents of the test. CVI is the average CVR value of all items

$$
C V I=\frac{\text { The total } C V R}{\text { number of items }}
$$

The category of CVR and CVI calculation results range of CVR and CVI values is $-1<0<1$. The numbers are categorized as follows:

$$
\begin{aligned}
-1<x<0 & =\text { not good } \\
0 & =\text { good } \\
0<x<1 & =\text { very good }
\end{aligned}
$$

Reliability in this study used the Borich method, known as the Percentage Agreement (PA) that is the percentage of agreements between assessors that is a percentage of the value compatibility between the first assessor and the second assessor. Percentage Agreement (PA) can be formulated in equations (3).

$$
\mathrm{PA}=\left(1-\frac{\mathrm{A}-\mathrm{B}}{\mathrm{A}+\mathrm{B}}\right) 100 \%
$$

Description:

$\mathrm{A}=$ Larger score

$\mathrm{B}=$ Smaller score

Nasrah, (2017) states that the device validation result is declared reliable if the percentage value of $>75 \%$.

\section{Effectiveness Data Analysis}

To find out the improvement in learning outcomes, a pretest and posttest must be performed on the learners. The pretest is given to grade XI MIA 1 MAN 1 West Lombok students as many as 15 students. The pretest is done before the learning is done, while the postest is done after the learning ends. According to Hake in Evawani (2013), the N-Gain standard can be searched by using a formula in the equation (4).

$$
\text { Standar Gain }=\frac{\bar{x}_{\text {pretest }}-\bar{x}_{\text {postest }}}{100-x_{\text {pretest }}}
$$

Description:

$\overline{\mathrm{x}}_{\text {postest }}=$ average postest value

$\overline{\mathrm{x}}_{\text {pretest }}=$ average prestest value

$100=$ maximum value

The standard gain value is presented in the criteria in the following table.

Table 1. Standard Gain Interpretation

\begin{tabular}{lcl}
\hline No & Standard Value Gain & Criteria \\
\hline 1 & $(g) \geq 0,7$ & High \\
2 & $0,7>(g) \geq 0,3$ & Medium \\
3 & $(g)<0,3$ & Low \\
\hline
\end{tabular}

\section{Practicality Data Analysis}

1) Teacher Response Questionnaire

The practicality data of learning devices is obtained from the dampness of learning performance by the observer, and then analyzed to determine the average percentage with equations (5)

$$
\bar{x}=\frac{\text { total score }}{\text { maximum score }} \times 100
$$

The practicality of the instrument is determined based on the following table.

Table 2. Practicality Criteria

\begin{tabular}{lcl}
\hline No & Average score range & Level of practicality \\
1 & $80<x \leq 100$ & Very Practical \\
2 & $60<x \leq 80$ & Practical \\
3 & $40<x \leq 60$ & quite practical \\
4 & $20<x \leq 40$ & less practical \\
5 & $0<x \leq 20$ & impractical \\
\hline
\end{tabular}

2) Learner Response Questionnaire

Students' response questionnaires are analyzed by converting quantitative data (average scores of students) into qualitative data. Furthermore, the average of the students' response questionnaires is calculated using the formula in the equation (6).

$$
\bar{x}=\frac{\text { score obtained }}{\text { maximum score }} \times 100
$$

By using the score conversion guidelines to a scale value of five. The reference for converting the score to a scale of five is as in Table 3.

Table 3. Convert Percentage of Students' Responses

\begin{tabular}{lcl}
\hline No & Percentage $(\%)$ & Category \\
\hline 1 & $x>80$ & Excellent \\
2 & $60<x \leq 80$ & Good \\
3 & $40<x \leq 60$ & Enough \\
4 & $20<x \leq 40$ & Less \\
5 & $0<x \leq 20$ & Very Lacking \\
\hline
\end{tabular}

(Widoyoko, 2009) 


\section{3) T-count Test Analysis}

One of the testing methods used to assess effectiveness, characterized by an average difference before and after treatment. The basis of the decision to accept or reject Ho in this test is if the $t$ count $>t$ table, then Ho is rejected and Ha is accepted, whereas if $t$ count $<\mathrm{t}$ table, then Ho is accepted and Ha is rejected (Widiyanto, 2013). The equations of paired t-test samples are as follows.

$$
t=\frac{\bar{x}_{1}-\bar{x}_{2}}{\sqrt{\frac{s_{1}^{2}}{n_{1}}+\frac{s_{2}{ }^{2}}{n_{2}}-2 r\left(\frac{s_{1}}{n_{1}}\right)\left(\frac{s_{2}}{n_{2}}\right)}}
$$

Description:

$\overline{\mathrm{x}}_{1}=$ Average sample 1

$\overline{\mathrm{x}}_{2}=$ Average sample 2

$\mathrm{s}_{1}=$ Standard deviation sample 1

$\mathrm{s}_{2}=$ Standard deviation sample 2

$\mathrm{s}_{1}{ }^{2}=$ Variance sample 1

$\mathrm{s}_{2}{ }^{2}=$ Variance sample 2

$\mathrm{r}=$ Correlation between two samples.

\section{Result and Discussion}

The definition is done at several stages, namely preliminary analysis, student analysis, concept analysis, and learning objective analysis. The initial analysis obtained several problems namely the lack of interest in learning high school students in physics subjects because they consider physics subjects difficult and boring, materials mastery is still lacking because learning is still informative by teachers.

Furthermore, the analysis stage of students, where at this stage the child has the ability to think logically and abstractly. These capabilities form the basis and consideration in the preparation of learning devices. Concept analysis aims to identify and compile the mapping of materials learned by students. While the analysis of learning objectives describes the processes and results that students will achieve.

After doing the next defining stage is done the design stage. Learning devices developed in the form of syllabus, lesson plan, student worksheet, and test instruments learn results in elasticity material. The things that are done at this stage are to develop research devices that make syllabus, lesson plan, student worksheet, and test instruments of study results.

The next stage is the development stage, at this stage is done product manufacturing, product validation by experts, and product trials to students. Products that have been created are validated by the validator and then revised based on suggestions and feedback from the validator. If the learning device that has been done validated by experts shows valid results then it is said to be worth using to improve the learning outcomes of students. The syllabus validity instrument has 9 statement items, lesson plan has 6 statement items, worksheet has 7 statement items and there are 7 learning test items.

Furthermore, to see the device is said to be effective by doing the predictors and postest to the learners. The instrument used is a test instrument of study results consisting of 15 items of multiple-choice questions. As for looking at the device can be said to be practical that is to give the question of learning implementation response to the teacher of the subject, give the test instrument response questionnaire to the learner and calculate the $\mathrm{t}$-test to see the difference in scores in the before learning and after learning.

The results of the study are quantitative and qualitative data. Quantitative data is obtained from the score of each aspect item assessed, while qualitative data is obtained from suggestions and feedback provided by validators, teachers, and students. As for the results of the assessment of validity, effectiveness, and practicality.

Table 4. Validity Test Results

\begin{tabular}{llcl}
\hline No & Validator & CVI & Category \\
\hline 1 & Syllabus & 1 & Very Valid \\
2 & Lesson Plan & 1 & Very Valid \\
3 & Worksheet & 1 & Very Valid \\
4 & Test Instruments & 1 & Very Valid \\
\hline
\end{tabular}

Based on the table above it can be known that devices developed in the form of syllabus, lesson plan, students worksheet, and instrument tests can be categorized as very valid.

Tabel 5. Hasil Uji Reliabilitas

\begin{tabular}{llll}
\hline No & Validator & $\begin{array}{l}\text { Percentage } \\
\text { Agreement (PA) (\%) }\end{array}$ & Category \\
\hline 1 & Syllabus & 97.8 & Reliable \\
2 & Lesson Plan & 95.8 & Reliable \\
3 & Worksheet & 95.4 & Reliable \\
4 & Test Instruments & 95.4 & Reliable \\
\hline
\end{tabular}

Based on the table above the device developed in the form of syllabus, lesson plan, students worksheets, and test instruments can be said reliable. This is based on the Percentage Agreement (PA) above 75\%.

Table 6. Summary of Pre-Test, Post Test and N-gain indexes

\begin{tabular}{llll}
\hline No & & Pre-test & Post-test \\
\hline 1 & Sum & 640 & 1138 \\
2 & Average & 42.67 & 75.87 \\
3 & N-gain & 0.56 & \\
4 & Description & Medium & \\
\hline
\end{tabular}

Based on the table above the pretest and postest analysis results get an $\mathrm{N}$-gain value of 0.56 can be said to be a moderate category. 
Table 7. Teacher Response Implementation Questionnaire Results

\begin{tabular}{llll}
\hline No & Validator & Average (\%) & Category \\
\hline 1 & Lesson Plan & 85.7 & Very practical \\
2 & Worksheet & 86.6 & Very practical \\
3 & Test Instruments & 91.6 & Very practical \\
\hline
\end{tabular}

Based on the table above the results of the poll implementation of the teacher's response stated that learning devices are categorized as very practical.

Table 8. Pre-test and post-test $t$-count analysis

\begin{tabular}{clll}
\hline No & & pre-test & post-test \\
\hline 1 & Average & 42.67 & 75.87 \\
2 & standard deviation & 19.81 & 14.25 \\
3 & Variance & 392.38 & 203.12 \\
4 & T-count test & -7.21 & \\
5 & t table & 2.04 & \\
\hline
\end{tabular}

Based on the table above the test $\mathrm{t}$-count analysis is obtained by -7.21 (- $\mathrm{t}_{\text {table }}<\mathrm{t}_{\text {count }}<\mathrm{t}_{\text {table}}$ ), which means there is a difference in average score before and after learning.

The purpose of this research is to produce phet simulation-assisted guided inquiry model learning devices on valid, effective, and practical elasticity materials. This research uses Research and Development (R\&D) research methods with research models developed are 4D Models consisting of defining stage, design, development, and disseminate.

The validity, effectiveness, and practicality of phet simulation-assisted inquiry model learning devices can be seen based on validator assessments, teacher response questionnaires, student response questionnaires, and results from the analysis.

The syllabus is arranged in accordance with the curriculum in which there are indicators, learning activities, forms of assessment, and allocation of time. The validity of the syllabus can be determined from the validation results by the expert validator. The validation analysis of all six validators is calculated using CVR and CVI. Based on its analysis obtained CVR and CVI value of 1 or categorized very valid. The reliability of the syllabus is calculated using percentage agreement analysis. The device is said to be reliable if the Percentage Agreement is above $75 \%$ or equal to $75 \%$. The percentage agreement value on the syllabus is $97.8 \%$ indicating that the syllabus is declared reliable.

The Learning Implementation Plan is prepared as a guideline in the implementation of the learning process. Lesson plan validity can be determined from validation results by expert validators. The validation analysis of all six validators is calculated using CVR and CVI. Based on its analysis obtained CVR and CVI value of 1 or categorized very valid. For reliability of lesson plan is calculated using Percentage Agreement analysis. The device is said to be reliable if the Percentage
Agreement is above $75 \%$ or equal to $75 \%$. The percentage agreement value of lesson plan is $95.8 \%$ indicating that lesson plan is declared reliable.

The Learner Worksheet is a guide for students used as an investigation activity to solve problems (Sahidu, 2016). Worksheet validity can be determined from validation results by expert validators. The validation analysis of all six validators is calculated using CVR and CVI. Based on its analysis obtained CVR and CVI value of 1 or categorized very valid. The reliability of the worksheet is calculated using percentage agreement analysis. The device is said to be reliable if the Percentage Agreement is above $75 \%$ or equal to $75 \%$. The percentage agreement value of worksheet is $95.4 \%$ indicating that students worksheet is declared reliable.

A test instrument is used as a measuring instrument against learning achievement. The instrument test developed is a test of students' learning results. The validity of the learning results test instrument can be determined from the validation results by the expert validator. The validation analysis of all six validators is calculated using CVR and CVI. Based on its analysis obtained CVR and CVI value of 1 or categorized very valid. As for the reliability of the test instruments, the learning results are calculated using percentage agreement analysis. The device is said to be reliable if the Percentage Agreement is above $75 \%$ or equal to $75 \%$. The percentage agreement value on the study instrument is $97.8 \%$ indicating that the test instrument of the study results is declared reliable.

Analysis of pretest and posttest results using Ngain has obtained an average of 0.56 which means the difference in pretest and posttest study results is in the moderate category.

The results of the learning device practicality analysis are obtained from student response questionnaires and teacher response questionnaires. The results of teacher response analysis were obtained on average 87.9 which means very practical, analysis of the response data of students to the test instrument of the study results filled by 15 students, obtained an average response of students $86 \%$, where the instrument belongs to the category is very good. While the results of the $t-$ count test analysis are obtained from the pretest and posttest results of the learners so that the t-count test analysis is -7.21 ( $-\mathrm{t}$ table $<\mathrm{t}$ count $<\mathrm{t}$ table), which means there is a difference in the average score before and after the use of learning devices.

\section{Conclusion}

Phet simulation-assisted inquiry model learning devices on elasticity materials are worth using and fall into a very valid category with a score range of $1-5$. So it 
can be concluded that the development of Syllabus, lesson Plan, Worksheet, and Learning Results Test Instruments guided by phet simulation of elasticity materials can be said to be valid and worthy of use as a learning device. Phet simulation-assisted inquiry model learning device ineffective elasticity material used is reviewed from improved learning outcomes of students with a moderate N-Gain value of 0.56 . Phet simulationassisted inquiry model learning device in elasticity material meets the practical and easy-to-use category with $87.9 \%$ teacher response results with very practical category, students give $86 \%$ positive or excellent response. Meanwhile, the t-count test analysis got -7.21 so it can be said that there is a difference in average scores before and after the study.

\section{References}

Abidin, Y. (2014). Desain Pembelajaran dalam Konteks Kurikulum 2013. Bandung: PT Replika Aditama. [Indonesian]

Borg, W.R., \& Gall, M.D. (1983). Educational reseach an introduction. New York: Longman. [Indonesian]

Borich, G.D. (1994). Observation Skill for Effective Teaching. NewYork: Mac Millian Publishing company

Depdiknas. (2003). Undang-Undang Republik Indonesia nomor 20 tahun 2003. Jakarta Departemen Pendidikan Nasional Republik Indonesia. [Indonesian]

Widoyoko, E.P.S. (2009). Evaluasi Program Pembelajaran. Yogyakarta: Pustaka Pelajar. [Indonesian]

Evawani, T., Rahayu, E. S. \& Retnoningsih, A. 2013. Pengembangan Perangkat Pembelajaran Bermakna Menggunakan Lembar Kerja Siswa Divergen Pada Materi Ciri-ciri Makhluk Hidup. Journal of Educational Research and Evaluation. 2(1). Retrieve

From: https://journal.unnes.ac.id/sju/index.php/jere /article/view/1333. [Indonesian]

Finkelstein, ND., Adas, WK., Keller, CJ., Kohl PPB., Perkins, KK., Podolefsky, NS., Reid, S., \& LeMaster, R. (2005). When learning about the real world is better done virtually: A study of substituting computer simulations for laboratory equipment. Physical Review Special Topics - Physics Education Research, 1(1) p. 010103

Gunawan. (2015). Model Pembelajaran Sains Berbasis ICT. Mataram: FKIP UNRAM. Indonesian

Kholifudin, M.Y. (2012). Pembelajaran Fisika Dengan Inkuiri Terbimbing Melalui Metode Eksperimen dan Demonstrasi Ditinjau dari Gaya Belajar Siswa. Prosiding Pertemuan Ilmiah XXVI HFI Jateng \& DIY, Purworejo 14 April 2012. ISSN : 0853-0823

Maliyah, N., Sunarno, W., \& Suparmi. (2012).
Pembelajaran Fisika Dengan Inkuiri Terbimbing Melalui Metode Eksperimen dan Demonstrasi Diskusi Ditinjau dari Kemampuan Matematik dan Kemampuan Verbal Siswa. Jurnal Inkuiri. 1(3).227-234. [Indonesian]

Nasrah, N., Jasruddin, J., \& Tawil, M. (2017). Pengembangan Perangkat Pembelajaran Fisika Berbasis Pendekatan Contexstual Teaching And Learning (CTL) Untuk Memotivasi Dan Meningkatkan Hasil Belajar Fisika Peserta Didik Kelas VIII SMP Negeri 1 Balocci Pangkep. Jurnal Pendidikan Fisika, 5(2), 235-248. doi:https://doi.org/10.26618/jpf.v5i2.709. [Indonesian]

Sahidu, H. (2016). Pengembangan Program Pembelajaran Fisika (P3F). Matram: FKIP UNRAM. [Indonesian]

Sari, P., Gunawan, G., \& Harjono, A. (2017). Penggunaan Discovery Learning Berbantuan Laboratorium Virtual pada Penguasaan Konsep Fisika Siswa. Jurnal Pendidikan Fisika dan Teknologi, 2(4), 176-182. doi:http://dx.doi.org/10.29303/jpft.v2i4.310. [Indonesian]

Sarwi., \& Khanafiyah, S. (2010). Pengembangan Keterampilan Kerja Ilmiah Mahasiswa Calon Guru Fisika Melalui Eksprimen Gelombang Open Inquiry. Jurnal Pendidikan Fisika Indonesia 6 (2). 115-122.

doi:https://doi.org/10.15294/ipfi.v6i2.1123. [Indonesian]

Susdarwati., Saranto., \& Cari. (2016). Pengembangan Perangkat Pembelajaran Fisika Berbasis Problem Based Learning (PBL) pada Materi Hukum Newton dan Penerapannya Kelas X SMAN 2 Mejayan. Jurnal Inkuiri, 5(3), 1-11. doi: https://doi.org/10.20961/inkuiri.v5i3.9434. [Indonesian]

Tanjung, H.S., \& Nababan, S.A. (2018). Pengembangan Perangkat Pembelajaran Matematika Masalah (PBM) Untuk Meningkatkan Kemampuan Berpikir Kritis Siswa SMA se Kuala Nagan Raya Aceh. Genta Mulia: Jurnal Ilmiah Pendidikan, 9(2). [Indonesian]

Thiagarajan \& Sivasailam. (1974). Pengembangan Instruksional untuk Guru Pelatihan Anak Luar Biasa: Buku Sumber. Indiana: Universitas Indiana. [Indonesian]

Wulandari, R. (2014). Pengaruh Model Pembelajaran Inkuiri Terbimbing terhadap Hasil Belajar Siswa SMAN 1 Pasuruan. Tesis. Pendidikan Geografi, Pascasarjana Universitas Negeri Malang. [Indonesian] 